Article

\title{
High Temperature Corrosion Behaviors of 20G Steel, Hastelloy C22 Alloy and C22 Laser Coating under Reducing Atmosphere with $\mathrm{H}_{2} \mathrm{~S}$
}

\author{
Zongde Liu *(D), Congcong Liu, Yuan Gao and Chao Zheng \\ Key Laboratory of Energy Transfer and System of Power Station of Ministry of Education, North China Electric \\ Power University, Beijing 102206, China; jylcc5613@163.com (C.L.); 18810178944@163.com (Y.G.); \\ zhengkirk@aliyun.com (C.Z.) \\ * Correspondence: lzd@ncepu.edu.cn; Tel.: +86-185-1543-5590
}

Received: 30 May 2020; Accepted: 23 June 2020; Published: 29 June 2020

check for updates

\begin{abstract}
High-temperature corrosion behaviors of 20G steel, Hastelloy C22 alloy and C22 laser coating was evaluated by corrosion mass gain measurements at $450{ }^{\circ} \mathrm{C}$. The corrosive atmosphere is $0.2 \mathrm{vol} \% \mathrm{H}_{2} \mathrm{~S}-0.1 \mathrm{vol} \% \mathrm{O}_{2}-\mathrm{N}_{2}$, which simulated the severe high-temperature corrosion environment occurred under low- $\mathrm{NO}_{\mathrm{x}}$ combustion in pulverized-coal furnaces. Experimental results showed that the corrosion resistance of the C22 laser coating and the C22 alloy was obviously better than 20G steel. Furthermore, it should be noted that the C22 laser coating fabricated in this study displayed a higher corrosion resistance than the commercial C22 alloy although they had the same chemical composition. The severe pitting corrosion was observed in 20G steel with the corrosion products consisting of $\mathrm{FeS}_{2}$, $\mathrm{Fe}_{2} \mathrm{O}_{3}$ and $\mathrm{Fe}_{3} \mathrm{O}_{4}$. The $\mathrm{C} 22$ alloy and $\mathrm{C} 22$ laser coating exhibited the uniform corrosion and their main corrosion products were $\mathrm{NiS}_{2}, \mathrm{CrS}$ and a small amount of chromium and manganese oxides.
\end{abstract}

Keywords: high temperature corrosion; reducing atmosphere; $\mathrm{H}_{2} \mathrm{~S}$; $\mathrm{C} 22$ laser coating

\section{Introduction}

With environmental issues becoming more prominent, low- $\mathrm{NO}_{\mathrm{x}}$ combustion technology have been widely applied in pulverized-coal furnaces. The basic design principle for the low $-\mathrm{NO}_{\mathbf{x}}$ combustion is to delay the mixing between fuel and air to create a region of low temperature reducing atmosphere, then the $\mathrm{NO}_{\mathrm{x}}$ formation reactions can be inhibited [1-3]. However, high-temperature corrosive gases of $\mathrm{H}_{2} \mathrm{~S}$ resulting from the low- $\mathrm{NO}_{x}$ combustion are produced, and the gases even cannot be completely oxidized before flowing out of the furnace [4-7]. The water wall tubes suffer more severe high temperature corrosion in reducing atmosphere, because the $\mathrm{H}_{2} \mathrm{~S}$ can react with water wall to form porous, nonadherent, sulfide scale without protection [5-8]. The pressure and temperature of steam will be continuously increased with the application of supercritical and ultrasupercritical utility boilers, and a large number of experiments have shown that the corrosion mass gain increases with the increase of temperature $[5,9,10]$. Therefore, it is necessary to develop high corrosion resistant materials in the pulverized-coal furnaces with low- $\mathrm{NO}_{x}$ combustion.

As an inactive element chemically, nickel-based alloys are widely used in modern industry for their ability of exceptional corrosion resistance [11-14]. As one of the nickel based alloys, Hastelloy C22 alloy has been studied extensively because of the outstanding resistance to pitting corrosion [15], crevice corrosion [16-20] and stress-corrosion cracking [21]. Studies have shown that $\mathrm{Cr}$ and Mo as one of the main alloying elements of $\mathrm{C} 22$ alloy can decrease corrosion rates by forming a thin chemically impervious surface [22-24], and Cr plays the a major role in maintaining passivity, while Mo plays a leading role in enhancing the passivation capacity of the passivation film after breakdown $[23,25,26]$. 
Moreover, C22 has been shown to have good corrosion resistance by forming dense oxides on the surface in high temperature molten salt corrosion environment [18] and is one of the few materials that are resistant to corrosive by solution containing hydrogen sulfide [27]. But few studies were aimed at high-temperature corrosion in reducing atmosphere, especially $\mathrm{H}_{2} \mathrm{~S}$ corrosion of in the pulverized-coal furnaces with low-NOx combustion.

Considering that nickel metal is the deficient resource-and C22 alloy is more expensive than conventional wrought alloys [28] —it is not a suitable candidate of water wall tube for pulverized-coal furnaces. With superior surface properties of high energy density, metallurgical bonding, low dilution rate, refined microstructure, pore-free and small heat affected zone [29-34], laser-cladding technology shows dramatic potential to prepare corrosion resistant coatings. Generally, a cladding layer with a thickness of 300-500 $\mu \mathrm{m}$ has good corrosion resistance, which can significantly reduce the material cost and the comparative studies [18,35] show the hot corrosion resistance of C22 laser coating is better than that of C22 alloy. Thus, the preparation of C22 laser coating on 20G-steel surface by laser-cladding technology can significantly reduce the cost and improve the corrosion resistance.

In this study, in order to reduce the corrosion caused by low- $\mathrm{NO}_{x}$ combustion in pulverized-coal furnaces, C22 laser coating was prepared on a 20G surface. At the same time, to investigate effect of $\mathrm{H}_{2} \mathrm{~S}$ gas on the corrosion behavior of materials, a comparative study of 20G steel, C22 alloy and the C22 laser coating was carried out and the experimental results were discussed in detail.

\section{Materials and Methods}

\subsection{Materials and Laser-Cladding Process}

The materials investigated in the study were $\mathrm{C} 22$ laser coating prepared on the substrate of water wall tube of 20G steel [36], the Hastelloy C22 alloy bar and 20G steel cut from water wall tube. The C22 powder (offered by Beijing General Research Institute of Mining and Metallurgy) used for the laser cladding on the surface of water-wall tubes of 20G steel was 250-300 mesh. The laser-cladding system used in the study was composed of a laser-cladding workbench, a pulsed fiber laser (ZKZM-2000, $\mathrm{Xi}^{\prime}$ an, China) with power of $2000 \mathrm{~W}$ and beam spot of $1.4 \mathrm{~mm}$ in diameter as the energy source, a self-designed synchronous powder feeder. To prevent oxidation in cladding process, the powder of $\mathrm{C} 22$ was transported by carrier gas of argon with flow rate of $5 \mathrm{~L} / \mathrm{min}$. The laser-cladding parameter: power, $2000 \mathrm{~W}$; scan speed, $5 \mathrm{~cm} / \mathrm{s}$, overlap rate: $50 \%$, single-clad thickness: $500 \mu \mathrm{m}$. In order to reduce the effect of dilution rate on the corrosion resistance of the C22 laser coating, the thickness of the C22 coating prepared by multitrack cladding process was made $5 \mathrm{~mm}$. The substrate of C22 laser coating was prepared from a 20G-steel water wall tube of diameter of $60 \mathrm{~mm}$, which was polished and then degreased with acetone before cladding. Photograph of laser-cladding setup is shown in Figure 1a and C22 laser coating on the surface of 20G steel is shown in Figure 1b.

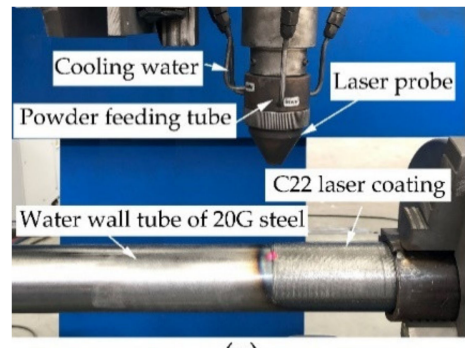

(a)

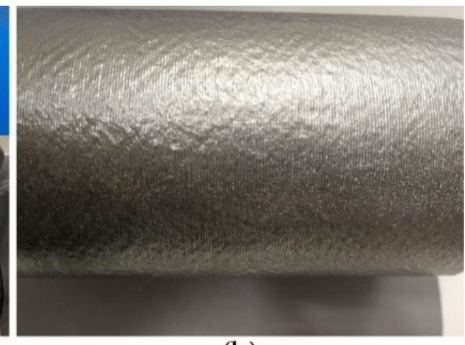

(b)

Figure 1. Photographs of: (a) laser-cladding setup; (b) C22 laser coating prepared on water wall tube surface of $20 \mathrm{G}$ steel.

As a contrast, the materials of the industrial alloy of Hastelloy C22 and the water wall tube material of 20G steel were also investigated. The chemical compositions of C22 powder, the Hastelloy C22 alloy and 20G steel are shown in Table 1. The specimens of C22 laser coating and 20G steel were 
obtained from the top $2 \mathrm{~mm}$ of the laser-cladding coating and water wall tube of 20G steel, respectively, the specimens of C22 alloy were cut form a forge piece made of C22 alloy bar. All of specimens were cut into cubes of $20 \mathrm{~mm} \times 10 \mathrm{~mm} \times 2 \mathrm{~mm}$ approximately and grounded using emery papers of 200-1200 grit sizes, then specimens were washed with distilled water and cleaned with acetone. For test accuracy, three parallel samples were prepared for each specimen.

Table 1. Chemical compositions of C22 powder, C22 alloy and 20G steel.

\begin{tabular}{|c|c|c|c|c|c|c|c|c|c|c|c|c|}
\hline \multirow{2}{*}{ Alloy } & \multicolumn{12}{|c|}{ Element (wt $\%)$} \\
\hline & $\mathrm{Ni}$ & $\mathrm{C}$ & $\mathrm{Cr}$ & Mo & Mn & $\mathrm{Fe}$ & $\mathrm{Si}$ & Co & $\mathbf{V}$ & $\mathbf{W}$ & $\mathrm{S}$ & $\mathbf{P}$ \\
\hline C22 powder & Bal. & 0.08 & 21.3 & 13.2 & - & 2.9 & - & 2.0 & & 3.0 & - & - \\
\hline C22 alloy & Bal. & 0.001 & 22.0 & 13.8 & 0.45 & 5.0 & 0.078 & 1.83 & 0.3 & 3.2 & 0.008 & 0.02 \\
\hline $20 G$ & - & $0.17-0.23$ & - & - & $0.35-0.65$ & Bal. & $0.17-0.37$ & - & - & - & $<0.015$ & $<0.025$ \\
\hline
\end{tabular}

\subsection{Hot Corrosion Studies}

High temperature corrosion tests were carried out in a horizontal tube furnace equipped with an alundum tube which is shown in Figure 2 (as same with $\mathrm{Xu}$ et al. [8]). The reducing corrosion system was primarily comprised of three parts: preparation of reducing atmosphere, sophisticated temperature control and exhaust gas treatment. The preprepared gas was controlled by the mass flow controller (MFC) to enter the mixing device and form the reducing atmosphere. The mixed gas passed into the closed high-temperature quartz tube and corroded with the pretreated samples. A tubular resistance furnace was used to carry out the isothermal corrosion from $12 \mathrm{~h}$ a cycle up to $108 \mathrm{~h}$ at $450{ }^{\circ} \mathrm{C}$. To avoid polluting the atmosphere, the flue gas from the quartz tube outlet was fed into the $\mathrm{NaOH}$ solution scrubber to remove the residual gas of $\mathrm{H}_{2} \mathrm{~S}$.

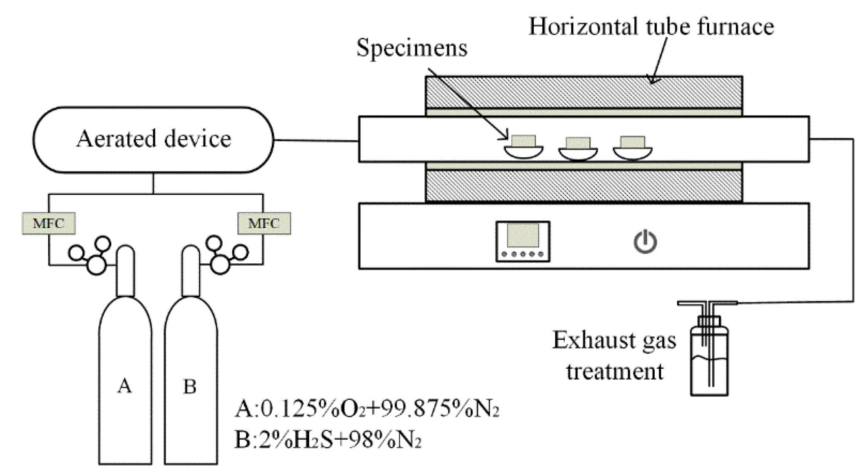

Figure 2. Experimental setup for the corrosion test.

In low- $\mathrm{NO}_{x}$ combustion, the corrosive medium near the low- $\mathrm{NO}_{x}$ burner area was $\mathrm{H}_{2} \mathrm{~S}$ and $\mathrm{CO}$ in the reducing atmosphere, and $\mathrm{CO}$ had a destructive effect on the protective film, forming a loose and porous $\mathrm{FeO}$ corrosion layer, and $\mathrm{S}$ and $\mathrm{H}_{2} \mathrm{~S}$ could penetrate the oxide film and react directly with the substrate resulting in accelerating corrosion rate [37]. In the actual corrosion environment, the volume fraction of $\mathrm{H}_{2} \mathrm{~S}$ gas was $0.05 \%-0.10 \%$, volume fraction of $\mathrm{O}_{2}$ was less than $0.5 \%$ [4]. Meanwhile, in the reducing atmosphere, there was a large amount of $\mathrm{CO}$ about $5 \%-10 \%$ and a certain linear relationship with $\mathrm{H}_{2} \mathrm{~S}$ [2]. The typical water wall temperature of pulverized-coal furnace was generally $400-450{ }^{\circ} \mathrm{C}$. In order to study the effect of $\mathrm{H}_{2} \mathrm{~S}$ on corrosion product of the materials of 20G, C22 alloy and C22 laser coatings in reducing atmosphere by low-NOx combustion in pulverized-coal furnaces, a mixture gas of $0.2 \mathrm{vol} \% \mathrm{H}_{2} \mathrm{~S}-0.1 \mathrm{vol} \% \mathrm{O}_{2}-\mathrm{N}_{2}$ was used to simulate the gaseous corrosion of $\mathrm{H}_{2} \mathrm{~S}$ at high temperature. Due to the low content of $\mathrm{H}_{2} \mathrm{~S}$ and $\mathrm{O}_{2}$ in reducing corrosive atmosphere, $\mathrm{H}_{2} \mathrm{~S}$ and $\mathrm{O}_{2}$ were premixed with $\mathrm{N}_{2}$ (balance gas) to reduce the experimental error, the mixing ratio column was shown in Figure 2 and the total gas flow rate in the experiment was $80 \mathrm{~mL} / \mathrm{min}$. The experimental temperature was set by a sophisticated temperature control instrument, which was connected to a thermocouple installed at 
the isothermal area of the horizontal tube furnace within error of $\pm 1^{\circ} \mathrm{C}$ and the experimental temperate was set at $450^{\circ} \mathrm{C}$. Because the samples stayed in a flowing reducing atmosphere, and isothermal zone of the horizontal tube furnace was in a restricted zone the crucible boat $(80 \mathrm{~mm} \times 20 \mathrm{~mm} \times 15 \mathrm{~mm}$ ) used to place the three parallel samples were fixed in the same place at the isothermal area to keep data consistency and experimental reproducibility.

Mass gain rate of corrosion was measured to evaluate the corrosion resistance of specimens according to the formula:

$$
\gamma=\frac{\Delta \mathrm{m}}{\mathrm{A} \cdot \mathrm{T}}
$$

where $\Delta \mathrm{m}$ is the average cumulative mass gain of three parallel specimens, i.e., the weight after the current corrosion minus the initial weight of the specimens, A is the average surface area of the parallel specimens measured prior to corrosion used screw-thread micrometer with the accuracy of $0.1 \mu \mathrm{m}$. T is the corrosion time, and $\gamma$ is the mass gain per unit area. When a corrosion cycle was finished, the crucible boats were taken out immediately and left cooling to room temperature, then weighed used the electronic micro-balance with accuracy of $0.1 \mathrm{mg}$.

In order to determine the corrosion behavior of 20G steel, C22 alloy and C22 laser coating, the corrosion morphology and composition were observed through scanning electron microscopy (SEM, FEI Quanta 200F, Brno, Czech Republic) equipped EDS (EDAX, Mahwah, NJ, USA) after finishing the last corrosion cycle. The e-beam resolution of the EDS used was $123 \mathrm{eV}$. The acceleration voltage was set at $20 \mathrm{kV}$ and the spot size of e-beam was about $1 \mu \mathrm{m}$. It had a detection limit of $0.1 \%$. At the same time, in order to observe the corrosion morphology of cross section after corrosion, one of the three parallel samples was embedded in the epoxy resin. The embedded samples were wet-ground through successive emery papers of 200-1200 grit sizes followed by polishing, cleaning used alcohol and then observed by SEM and EDS. Phase identification of the corrosion products was performed on the bulk samples by Rigaku D/max-rA X-ray diffract meter (Tokyo, Japan) with $\mathrm{Cu} \mathrm{K} \alpha$ radiation at $40 \mathrm{kV}$ and $40 \mathrm{~mA}$, between $2 \theta$ angles of $10^{\circ}$ and $100^{\circ}$ at a scanning rate of $8^{\circ} / \mathrm{min}$.

\section{Results}

\subsection{Corrosion Dynamics Curve}

Figure 3 presents the average mass gain of 20G steel, C22 alloy and C22 laser coating corroded in reducing atmosphere composted with $0.2 \mathrm{vol} \% \mathrm{H}_{2} \mathrm{~S}-0.1 \mathrm{vol} \% \mathrm{O}_{2}-\mathrm{N}_{2}$ for $108 \mathrm{~h}$ at $450^{\circ} \mathrm{C}$. As can be seen from Figure 3, there was a linear relationship between corrosion mass gain and time at temperature of $450^{\circ} \mathrm{C}$ and the average corrosion rate was $2.76 \times 10^{-1} \mathrm{mg} /\left(\mathrm{cm}^{2} \cdot \mathrm{h}\right)$. The corrosion regulation of $\mathrm{C} 22$ alloy and C22 laser coating was similar from the corrosion mass gain curve. The corrosion process was divided into two stages, the first stage was $0-12 \mathrm{~h}, \mathrm{C} 22$ alloy and C22 laser coating had a significant corrosion mass gain (shown in Figure 4), and the corrosion rated were $1.156 \times 10^{-2} \mathrm{mg} /\left(\mathrm{cm}^{2} \cdot \mathrm{h}\right.$ ), $1.048 \times 10^{-2} \mathrm{mg} /\left(\mathrm{cm}^{2} \cdot \mathrm{h}\right)$, respectively. The second stage was $12-108 \mathrm{~h}$, the corrosion mass gain of both tended to flatten out, and the slope of the corrosion weight gain curve of C22 alloy and C22 laser coating was not much different. In the second stage, the corrosion rate of C22 alloy and C22 laser coating were $6.194 \times 10^{-4} \mathrm{mg} /\left(\mathrm{cm}^{2} \cdot \mathrm{h}\right)$ and $5.740 \times 10^{-4} \mathrm{mg} /\left(\mathrm{cm}^{2} \cdot \mathrm{h}\right)$, respectively, which was far less than the corrosion mass gain in the first stage. As shown in Figures 3 and 4 , the corrosion resistance of C22 laser coating was better than that of C22 alloy, and the average corrosion rate of C22 laser coating was $1.68 \times 10^{-3} \mathrm{mg} /\left(\mathrm{cm}^{2} \cdot \mathrm{h}\right)$, which was less than $1.84 \times 10^{-3} \mathrm{mg} /\left(\mathrm{cm}^{2} \cdot \mathrm{h}\right)$ of $\mathrm{C} 22$ alloy. At the same time, due to the good corrosion resistance of $\mathrm{Ni}$ and $\mathrm{Cr}$ [8], the corrosion rates of C22 alloy and C22 laser coating were lower by two orders of magnitude compared to the $20 \mathrm{G}$ steels. 


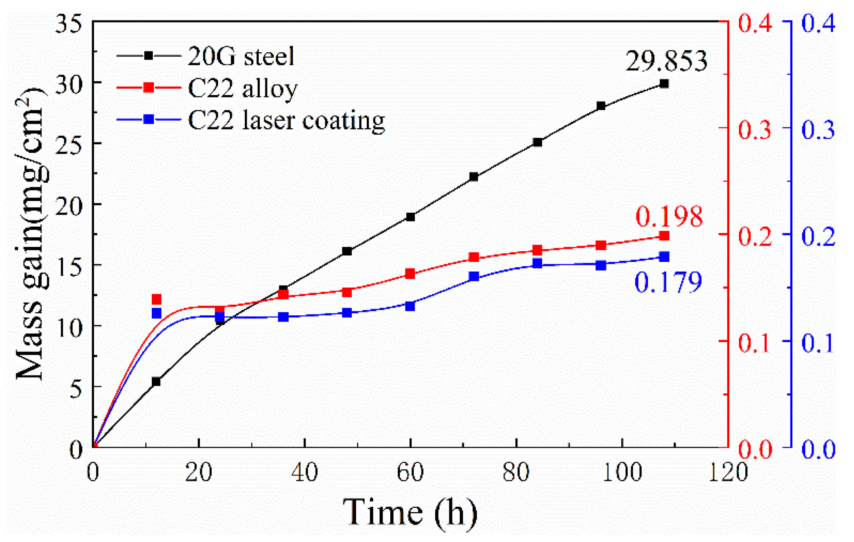

Figure 3. Average mass gain of $20 \mathrm{G}$ steel, C22 alloy and C22 laser coating corroded in reducing atmosphere for $108 \mathrm{~h}$ at $450{ }^{\circ} \mathrm{C}$.

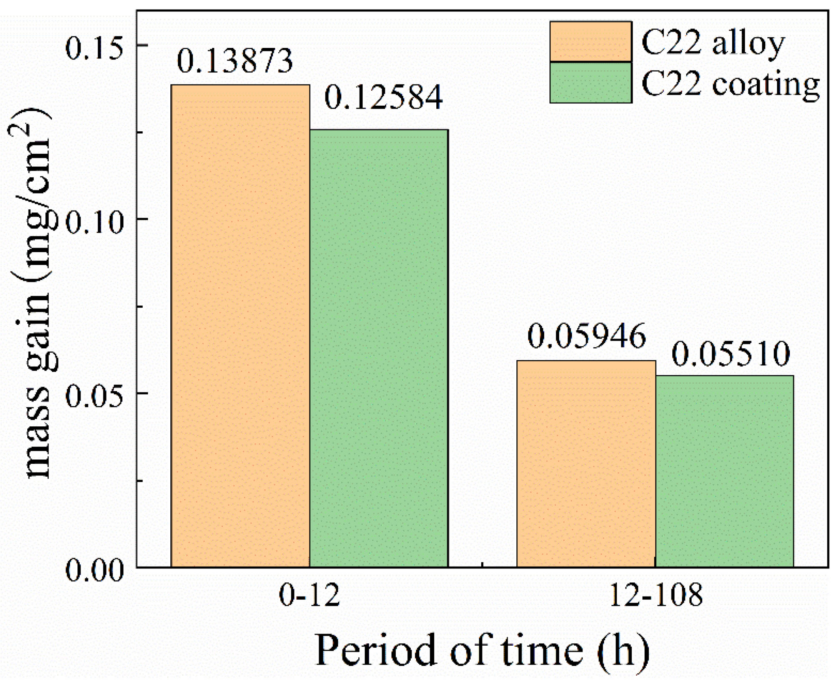

Figure 4. Comparison of corrosion mass gain between $0-12 \mathrm{~h}$ and 12-108 h of C22 alloy and C22 laser coating corroded in reducing atmosphere for $108 \mathrm{~h}$ at $450{ }^{\circ} \mathrm{C}$.

\subsection{Corrosion of 20G Steel, C22 Alloy and C22 Laser Coating}

Figure 5 shows the SEM surface micrographs of the corrosion products of $20 \mathrm{G}$ steel corroded in reducing environment of $0.2 \mathrm{vol} \% \mathrm{H}_{2} \mathrm{~S}-0.1 \mathrm{vol} \% \mathrm{O}_{2}-\mathrm{N}_{2}$ for $108 \mathrm{~h}$ at $450{ }^{\circ} \mathrm{C}$ and Table 2 shows EDS spot scan results of the corrosion products of $20 \mathrm{G}$ steel. At test temperatures, the specimen surface was covered by three layers of corrosion products and some cracks were observed. The outermost layer of corrosion was covered with a large number of scale-like corrosion products, as shown in Figure 5a1; The surface of middle layer (Figure 5b1) and the innermost layer (Figure 5c1) were present as particle-shaped phases, while the difference of them was that the particle of the middle layer surface was coarser and the innermost layer was smaller and smoother. According to EDS results as shown in Table 2, the main components of the corrosion products of outmost layer and the middle layer was (Fe, $\mathrm{O}, \mathrm{S})$-rich compositions, and ( $\mathrm{Fe}, \mathrm{S})$-rich compositions were identified as major phases in the corrosion products of the innermost layer. From the outmost layer to the innermost layer, the content of sulfur increased successively, while the content of oxygen decreased, and the innermost layer contains only elements Fe and S, no oxygen was found, which indicated that the substrate of 20G was first corroded to form sulfide of iron, then sulfides were oxidized by the oxygen with the corrosion time increased. 


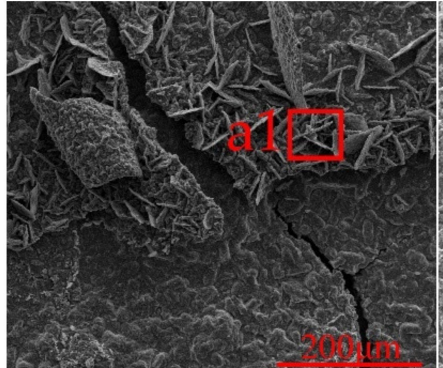

(a)

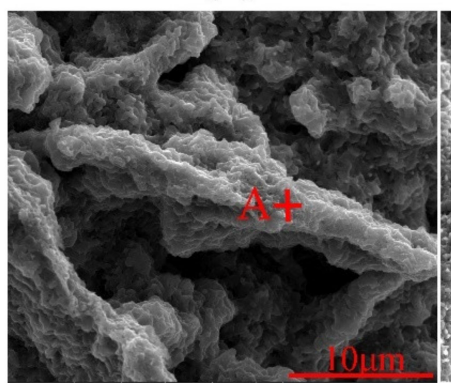

(a1)

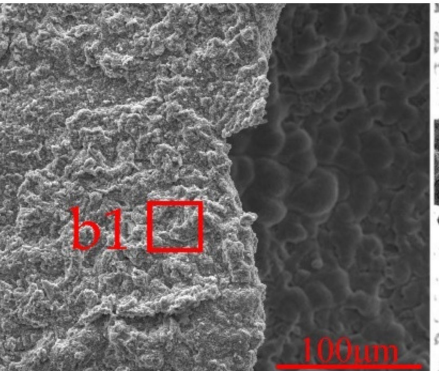

(b)

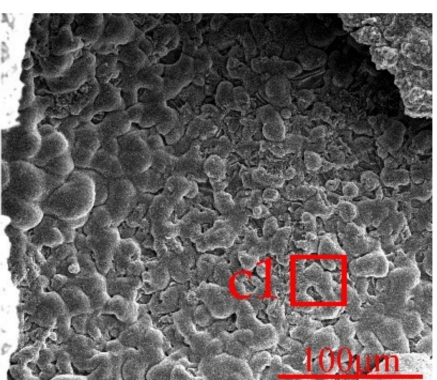

(c)

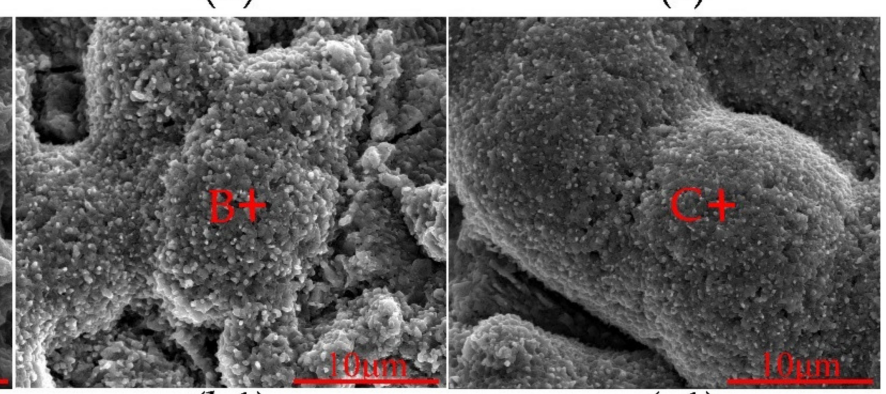

(b1)

(c1)

Figure 5. SEM surface micrographs of the corrosion products of: (a) outermost layer; (b) middle layer; (c) the innermost layer of $20 \mathrm{G}$ steel corroded in reducing atmosphere for $108 \mathrm{~h}$ at $450{ }^{\circ} \mathrm{C}$.

Table 2. EDS results for the typical phases of $20 \mathrm{G}$ steel corroded in reducing atmosphere for $108 \mathrm{~h}$ at $450{ }^{\circ} \mathrm{C}$ in Figure 5 .

\begin{tabular}{cccc}
\hline \multirow{2}{*}{ Title } & \multicolumn{3}{c}{ Elements (at\%) } \\
\cline { 2 - 4 } & S & Fe & O \\
\hline A & 18.78 & 27.97 & 53.24 \\
B & 21.25 & 39.64 & 39.10 \\
C & 69.30 & 39.70 & 0 \\
\hline
\end{tabular}

Figure 6 shows the SEM surface micrographs of the corrosion products of C22 alloy and C22 laser coating corroded in reducing environment of $0.2 \mathrm{vol} \% \mathrm{H}_{2} \mathrm{~S}-0.1 \mathrm{vol} \% \mathrm{O}_{2}-\mathrm{N}_{2}$ for $108 \mathrm{~h}$ at $450{ }^{\circ} \mathrm{C}$ and Table 3 shows EDS spot scan results of the corrosion products. The corrosion behavior and corrosion products of C22 alloy and C22 laser coating exhibit very similar. The corrosion morphology both were particle-shaped, and the corrosion products were mainly composed of ( $\mathrm{Ni}, \mathrm{Cr}$ )-rich sulfides and some oxides. Compared with 20G-steel corrosion, the corrosion layers of C22 alloy and laser coating had no stratification and the surface corrosion products were denser than the 20G steel, which may be the reason that corrosion mass gains of C22 alloy and C22 laser coating were divided into two stages. In the early stage, the corrosion media of $\mathrm{H}_{2} \mathrm{~S}$ and $\mathrm{S}$ penetrated more easily into the metal matrix. In the second stage of corrosion reaction, the osmotic pressure increased with the increase of corrosion products. However, since the corrosion products could not completely prevent the penetration of the corrosion media of $\mathrm{H}_{2} \mathrm{~S}$ and $\mathrm{S}$, the corrosion mass gain curve in the second stage was linear and the corrosion rate was lower than that in the first stage. At the same time, the corrosion products of C22 laser coating were denser than that of C22 alloy, and some cracks were observed as shown in Figure 6a, which may lead to the better corrosion resistance of C22 laser coating than C22 alloy (Figure 3) due to the refined microstructure of C22 laser coating [18,35]. 


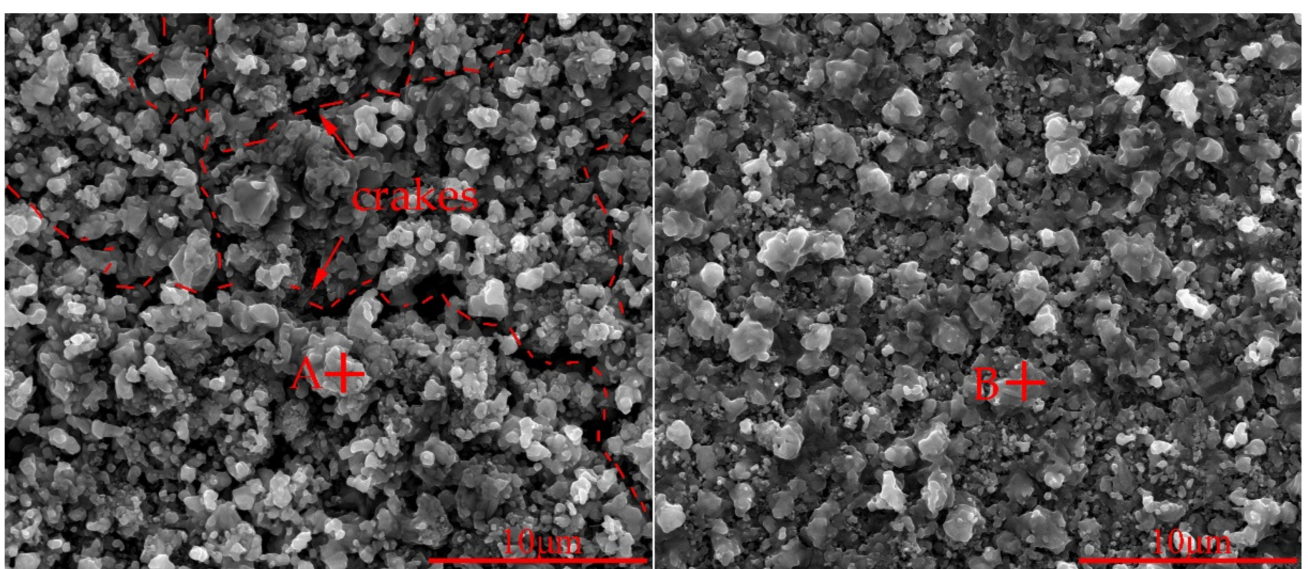

(a) (b)

Figure 6. SEM surface micrographs of the corrosion products of: (a) C22 alloy; (b) C22 laser coating corroded in reducing atmosphere for $108 \mathrm{~h}$ at $450{ }^{\circ} \mathrm{C}$.

Table 3. EDS results for the typical phases of C22 alloy and C22 laser coating corroded in reducing atmosphere for $108 \mathrm{~h}$ at $450{ }^{\circ} \mathrm{C}$ in Figure 6.

\begin{tabular}{cccccccccc}
\hline \multirow{2}{*}{ Point } & \multicolumn{10}{c}{ Elements (at\%) } \\
\cline { 2 - 11 } & Cr & S & Mn & Fe & Co & Ni & W & Mo & O \\
\hline A & 19.28 & 38.46 & 0.29 & 1.35 & 0.24 & 20.82 & 0.27 & 7.92 & 11.31 \\
B & 23.14 & 37.39 & 0.16 & 2.03 & 0.49 & 17.75 & - & 8.14 & 10.90 \\
\hline
\end{tabular}

Figure 7 displays the cross-sectional micrographs of 20G steel, C22 alloy and C22 laser coating corroded in reducing environment of $0.2 \mathrm{vol} \% \mathrm{H} 2 \mathrm{~S}-0.1 \mathrm{vol} \% \mathrm{O} 2-\mathrm{N} 2$ for $108 \mathrm{~h}$ at $450{ }^{\circ} \mathrm{C}$. For the 20G steel (Figure 7a), there were obvious pitting pits near the substrate, which indicated that the corrosion mechanism of 20G steel was mainly pitting corrosion. Nonadherent products were found and there was a large number of pores in the corrosion products. Therefore, corrosion products were not protective, and the corrosion medium was still easy to react with the matrix, which could explain that why the corrosion dynamics curve of 20G steel was linear. Compared to 20G steel, the corrosion mechanism of C22 alloy (Figure 7b) and C22 laser coating (Figure 7c) presented uniform corrosion due to the, only the alloy surface was corroded, but no pitting corrosion was found. Moreover, the corrosion layer thickness of C22 alloy was thicker than that of C22 laser coating, because the corrosion products of C22 laser coating were denser than that of C22 alloy.

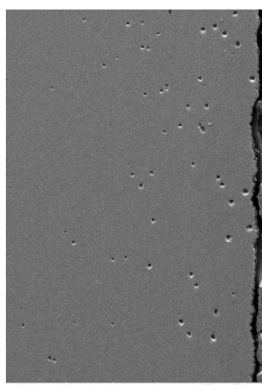

(a)

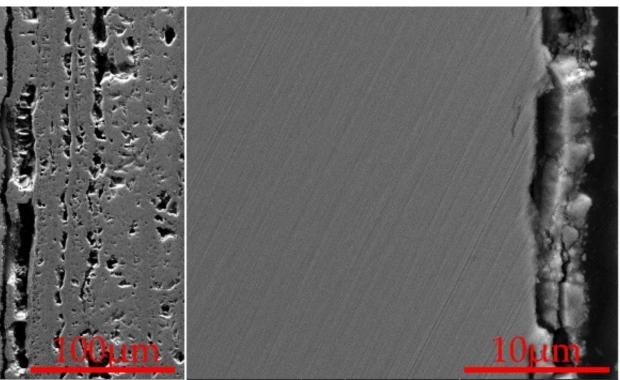

(b)

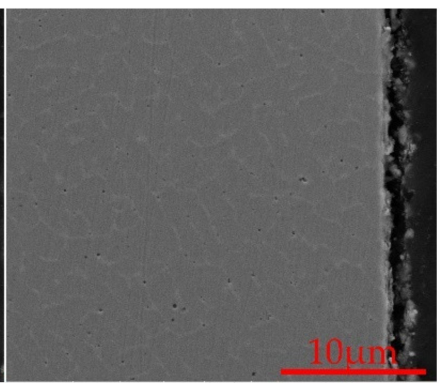

(c)

Figure 7. SEM cross-sectional micrographs of: (a) 20G steel; (b) C22 alloy; (c) C22 laser coating corroded in reducing atmosphere for $108 \mathrm{~h}$ at $450{ }^{\circ} \mathrm{C}$.

Figure 8 and Table 4 display the $\mathrm{X}$-ray diffraction patterns of corrosion products formed on the surfaces of 20G steel, C22 alloy, C22 laser coating corroded in $0.2 \mathrm{vol} \% \mathrm{H}_{2} \mathrm{~S}$-reducing environment 
for $108 \mathrm{~h}$ at $450^{\circ} \mathrm{C}$. A corrosion scale mainly composed of iron of oxides and sulfides, formed on the surface of $20 \mathrm{G}$ steel, and the Fe-rich peaks mainly correspond to $\mathrm{Fe}_{2} \mathrm{O}_{3}, \mathrm{Fe}_{3} \mathrm{O}_{4}$ and $\mathrm{FeS}_{2}$. Moreover, it could be found that the peaks of corrosion products of C22 laser coating and C22 alloy were the same, but the peak strength was different. At the same time, according to EDS resulted and XRD analysis, the major diffraction peaks correspond to $\mathrm{NiS}_{2}, \mathrm{CrS}$ and the sulfide $\left(\mathrm{Co}_{3} \mathrm{~S}_{4}, \mathrm{NiCo}_{2} \mathrm{~S}_{4}\right)$ was identified and $\mathrm{Cr}_{3} \mathrm{O}_{4}$ and $\mathrm{MnO}_{2}$ were identified.

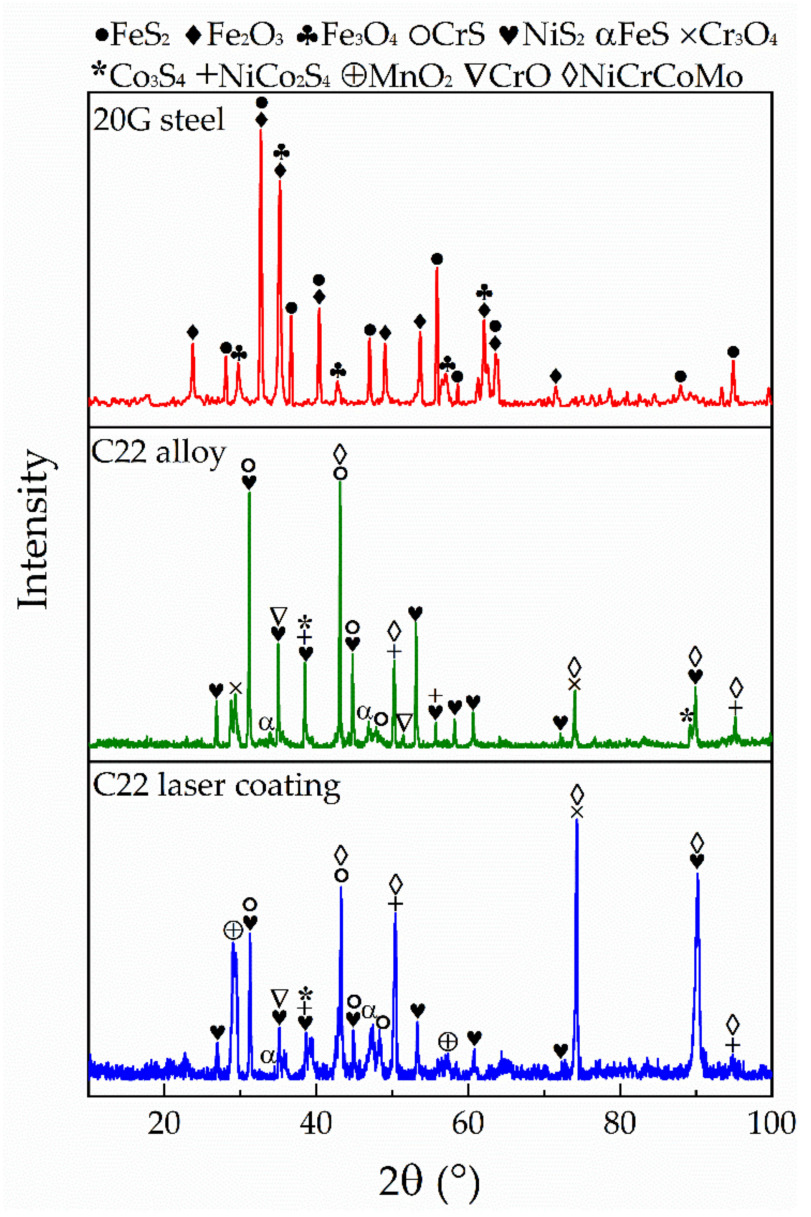

Figure 8. XRD patterns of corrosion products of 20G steel, C22 alloy and C22 laser coating corroded in reducing atmosphere for $108 \mathrm{~h}$ at $450{ }^{\circ} \mathrm{C}$.

Table 4. Phase constitution of corrosion products 20G steel, C22 alloy and C22 laser coating corroded in reducing atmosphere for $108 \mathrm{~h}$ at $450{ }^{\circ} \mathrm{C}$.

\begin{tabular}{cc}
\hline Title 1 & Phase Identification \\
\hline 20G steel & $\mathrm{FeS}_{2}+\mathrm{Fe}_{2} \mathrm{O}_{3}+\mathrm{Fe}_{3} \mathrm{O}_{4}$ \\
C22 alloy & $\mathrm{CrS}+\mathrm{NiS}_{2}+\mathrm{FeS}+\mathrm{Co}_{3} \mathrm{~S}_{4}+\mathrm{NiCo}_{2} \mathrm{~S}_{4}+\mathrm{Cr}_{3} \mathrm{O}_{4}+\mathrm{MnO}_{2}+\mathrm{CrO}+\mathrm{NiCrCoMo}$ \\
C22 laser coating & $\mathrm{CrS}+\mathrm{NiS}_{2}+\mathrm{FeS}+\mathrm{Co}_{3} \mathrm{~S}_{4}+\mathrm{NiCo}_{2} \mathrm{~S}_{4}+\mathrm{Cr}_{3} \mathrm{O}_{4}+\mathrm{MnO}_{2}+\mathrm{CrO}+\mathrm{NiCrCoMo}$ \\
\hline
\end{tabular}

\section{Discussion}

The corrosion resistance of materials at high temperatures was dependent on the formation of protective oxide scales. $\mathrm{H}_{2} \mathrm{~S}$ produced by low-nitrogen combustion in pulverized coal boilers is well known to be more corrosive than other oxidizing gases in high temperature corrosion, because it forms porous, nonadherent, sulfide scales that are not protective, which cause accelerated corrosion resulting in increased oxidation, metal wastage, internal attack. 
For the 20G steel-corrosion in reduction atmosphere for $108 \mathrm{~h}$ at $450{ }^{\circ} \mathrm{C}$, the corrosion process produced the porous, nonadherent, sulfide scale of surface of 20G steel (Figures 5 and $7 \mathrm{a}$ ), thus the corrosion products had no protective effect and the corrosion medium could be easy to pass through the corrosion products to directly corrode the substrate which resulted that corrosion dynamics curve was linear, and the corrosion rate was $2.76 \times 10^{-1} \mathrm{mg} /\left(\mathrm{cm}^{2} \cdot \mathrm{h}\right)$. The main corrosion products of $20 \mathrm{G}$ were $\mathrm{FeS}_{2}, \mathrm{Fe}_{2} \mathrm{O}_{3}, \mathrm{Fe}_{3} \mathrm{O}_{4}$ and a large number of sulfurs condensed at the outlet of the furnace due to the decrease of temperature. The formation of sulfur was mainly caused by the oxidation of $\mathrm{H}_{2} \mathrm{~S}$ and

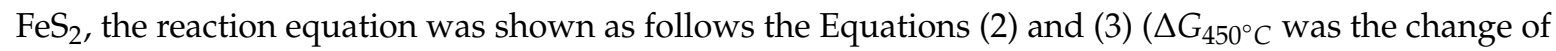
Gibbs free energy of the reaction equation) [9]:

$$
\begin{aligned}
3 \mathrm{FeS}_{2}+2 \mathrm{O}_{2} & \rightarrow \mathrm{Fe}_{3} \mathrm{O}_{4}+6 \mathrm{~S},\left(\Delta \mathrm{G}_{4500^{\circ} \mathrm{C}}=-466.461 \mathrm{~kJ}\right) \\
4 \mathrm{FeS}_{2}+3 \mathrm{O}_{2} & \rightarrow 2 \mathrm{Fe}_{2} \mathrm{O}_{3}+8 \mathrm{~S},\left(\Delta G_{4500^{\circ} \mathrm{C}}=-715.410 \mathrm{~kJ}\right) \\
2 \mathrm{H}_{2} \mathrm{~S}+\mathrm{O}_{2} & \rightarrow 2 \mathrm{~S}+2 \mathrm{H}_{2} \mathrm{O},\left(\Delta G_{450^{\circ} \mathrm{C}}=-326.089 \mathrm{~kJ}\right)
\end{aligned}
$$

According to the SEM and $\mathrm{XRD}$, the corrosion products were divided into three layers, the corrosion product of innermost layer was mainly fine and particle-shaped $\mathrm{FeS}_{2}$, without the presence of oxide, which indicts that reaction with matrix of $20 \mathrm{G}$ steel was mainly $\mathrm{S}$ and $\mathrm{H}_{2} \mathrm{~S}$, and the corrosion product was $\mathrm{FeS}_{2}$. Due to the co-existence of $\mathrm{S}$ and $\mathrm{H}_{2} \mathrm{~S}$, the corrosion reaction of the innermost layer of 20G steel was as follows the Equations (5) and (6):

$$
\begin{gathered}
\mathrm{Fe}+2 \mathrm{H}_{2} \mathrm{~S} \rightarrow \mathrm{FeS}_{2}+2 \mathrm{H}_{2},\left(\Delta \mathrm{G}_{450^{\circ} \mathrm{C}}=-46.228 \mathrm{~kJ}\right) \\
\mathrm{Fe}+2 \mathrm{~S} \rightarrow \mathrm{FeS}_{2},\left(\Delta G_{450^{\circ} \mathrm{C}}=-135.453 \mathrm{~kJ}\right)
\end{gathered}
$$

In the intermediate layer of the corrosion product, the corrosion product became rough, but it was still granular, and the presence of oxygen element was found in the corrosion product and according to XRD analysis, the oxides were mainly $\mathrm{Fe}_{2} \mathrm{O}_{3}$ and $\mathrm{Fe}_{3} \mathrm{O}_{4}$, which resulted from the oxidation of the innermost corrosion product of $\mathrm{FeS}_{2}$ by oxygen in the gas. As the corrosion time increased, the $\mathrm{FeS}_{2}$ in the corrosion layer was further oxidized and the and the morphology of the corrosion products changed from granular to scale-like. Thus, the corrosion reaction of the intermediate and outermost layer of 20G steel was as follows Equations (2), (3) and (7):

$$
4 \mathrm{Fe}_{3} \mathrm{O}_{4}+\mathrm{O}_{2} \rightarrow 6 \mathrm{Fe}_{2} \mathrm{O}_{3},\left(\Delta \mathrm{G}_{450^{\circ} \mathrm{C}}=-280.383 \mathrm{~kJ}\right)
$$

According to $\Delta G_{450^{\circ} \mathrm{C}}$ of Equations (5) and (6), although both $\mathrm{H}_{2} \mathrm{~S}$ and $\mathrm{S}$ could react with $\mathrm{Fe}, \mathrm{S}$ was easier to react with Fe compared with $\mathrm{H}_{2} \mathrm{~S}$, so $\mathrm{S}$ corrosion dominated in the corrosion process of 20G steel.

As shown in Figure 3, the corrosion rates of the C22 alloy and the C22 laser coating were $1.8351 \times 10^{-3} \mathrm{mg} /\left(\mathrm{cm}^{2} \cdot \mathrm{h}\right)$ and $1.6755 \times 10^{-3} \mathrm{mg} /\left(\mathrm{cm}^{2} \cdot \mathrm{h}\right)$, respectively, while the corrosion rate of $20 \mathrm{G}$ steel was $2.764 \times 10^{-1} \mathrm{mg} /\left(\mathrm{cm}^{2} \cdot \mathrm{h}\right)$. The corrosion resistance of the C22 alloy and the C22 laser coating was increased significantly as compared with that of $20 \mathrm{G}$ steel. At the same time, the fine granular corrosion products were distributed on the surface of C22 alloy and the C22 laser coating, but the corrosion products of $\mathrm{C} 22$ laser coating were denser than that of $\mathrm{C} 22$ alloy, resulting in a better corrosion resistance due to the refined microstructure of $C 22$ laser coating $[18,35]$ as shown in Figures 5 and 7.

The corrosion process of the C22 alloy and the C22 laser coating divided into two stage and Figure 4 shows the difference of mass gain between the two stages of the corrosion reaction. In the first stage of the reaction, $\mathrm{H}_{2} \mathrm{~S}$ and $\mathrm{S}$ contacted with the metal matrix directly and form the corrosion products easily-resulting in a high corrosion rate. In the second stage, the osmotic pressure of $\mathrm{H}_{2} \mathrm{~S}$ decreased with the increasing of corrosion products, which leads to a slow diffusion rate of $\mathrm{H}_{2} \mathrm{~S}$ to metal matrix [8], thus the corrosion rate of the second stage was slower than that of the first stage. 
According to XRD analysis (Figure 8), the corrosion products of C22 alloy and C22 laser coating were the same, consisting of sulfide (mainly composed $\mathrm{NiS}_{2}$ and $\mathrm{CrS}$ with some less $\mathrm{Co}_{3} \mathrm{~S}_{4}, \mathrm{NiCo}_{2} \mathrm{~S}_{4}$, $\left.\mathrm{Cr}_{2} \mathrm{~S}_{3}\right)$ and oxide $\left(\mathrm{Cr}_{3} \mathrm{O}_{4}\right.$ and $\left.\mathrm{MnO}_{2}\right)$. Moreover, large amounts of sulfur were deposited at the outlet of the furnace due to the low temperature during corrosion like the corrosion of $20 \mathrm{G}$ steel, thus the corrosion medias in the corrosion process of $\mathrm{C} 22$ alloy and $\mathrm{C} 22$ laser coating were $\mathrm{S}, \mathrm{H}_{2} \mathrm{~S}, \mathrm{O}_{2}$. Therefore, according to the corrosion process of 20G, the corrosion equation of $\mathrm{C} 22$ could be deduced as follow the Equations (4) and (8)-(15):

$$
\begin{aligned}
\mathrm{Ni}+2 \mathrm{H}_{2} \mathrm{~S} & \rightarrow \mathrm{NiS}_{2}+2 \mathrm{H}_{2},\left(\Delta G_{450^{\circ} \mathrm{C}}=-18.679 \mathrm{~kJ}\right) \\
\mathrm{Cr}+\mathrm{H}_{2} \mathrm{~S} & \rightarrow \mathrm{CrS}+\mathrm{H}_{2},\left(\Delta G_{450^{\circ} \mathrm{C}}=-94.431 \mathrm{~kJ}\right) \\
2 \mathrm{Cr}+3 \mathrm{H}_{2} \mathrm{~S} & \rightarrow \mathrm{Cr}_{2} \mathrm{~S}_{3}+3 \mathrm{H}_{2},\left(\Delta \mathrm{G}_{450^{\circ} \mathrm{C}}=-221.838 \mathrm{~kJ}\right) \\
3 \mathrm{Co}+4 \mathrm{H}_{2} \mathrm{~S} & \rightarrow \mathrm{Co}_{3} \mathrm{~S}_{4}+4 \mathrm{H}_{2},\left(\Delta \mathrm{G}_{450^{\circ} \mathrm{C}}=-124.473 \mathrm{~kJ}\right) \\
2 \mathrm{Ni}+2 \mathrm{~S} & \rightarrow \mathrm{NiS}_{2},\left(\Delta G_{450^{\circ} \mathrm{C}}=-107.903 \mathrm{~kJ}\right) \\
\mathrm{Cr}+\mathrm{S} & \rightarrow \mathrm{CrS}_{,}\left(\Delta G_{450^{\circ} \mathrm{C}}=-139.043 \mathrm{~kJ}\right) \\
2 \mathrm{Cr}+3 \mathrm{~S} & \rightarrow \mathrm{Cr}_{2} \mathrm{~S}_{3},\left(\Delta \mathrm{G}_{450^{\circ} \mathrm{C}}=-355.676 \mathrm{~kJ}\right) \\
3 \mathrm{Co}+4 \mathrm{~S} & \rightarrow \mathrm{Co}_{3} \mathrm{~S}_{4},\left(\Delta G_{450^{\circ} \mathrm{C}}=-302.923 \mathrm{~kJ}\right)
\end{aligned}
$$

Like the corrosion of 20G steel, the S corrosion dominated in the corrosion process of C22 alloy and C22 laser coating at $450{ }^{\circ} \mathrm{C}$ according $\Delta G_{450}{ }^{\circ} \mathrm{C}$ of Equations (8)-(15). Moreover, because the corrosion layer was very thin, there was no obvious stratification of the corrosion products of C22 alloy and C22 laser coating (the separation between the corrosion layer and the matrix was due to the external force during grinding process).

\section{Conclusions}

High temperature corrosion test of 20G steel, C22 alloy and C22 laser coating was conducted in $0.2 \mathrm{vol} \% \mathrm{H}_{2} \mathrm{~S}-0.1 \mathrm{vol} \% \mathrm{O}_{2}-\mathrm{N}_{2}$ at $450{ }^{\circ} \mathrm{C}$ (Simulating low- $\mathrm{NO}_{\mathrm{x}}$ combustion in pulverized-coal furnaces). The corrosion mass gain curve of $20 \mathrm{G}$ steel in the reducing atmosphere was linear. The corrosion process mainly produces $\mathrm{FeS}_{2}, \mathrm{Fe}_{2} \mathrm{O}_{3}$ and $\mathrm{Fe}_{3} \mathrm{O}_{4}$ which were porous and nonadherent without protection, and the corrosion mechanism was pitting. The nominal composition and corrosion products of $\mathrm{C} 22$ alloys was similar with that of $\mathrm{C} 22$ laser coating and the corrosion products of C22 alloy of C22 laser coating includes sulfide (mainly composed $\mathrm{NiS}_{2}$ and $\mathrm{CrS}$ ) and oxide $\left(\mathrm{Cr}_{3} \mathrm{O}_{4}\right.$ and $\left.\mathrm{MnO}_{2}\right)$. At the same time, the corrosion resistance of $\mathrm{C} 22$ laser coating was better than of $\mathrm{C} 22$ alloy due to the refined microstructure of $\mathrm{C} 22$ laser coating. Consequently, the $\mathrm{C} 22$ coating fabricated by laser-cladding method on the surface of $20 \mathrm{G}$ was an effective method to improve the corrosion resistance of it.

Author Contributions: Conceptualization, Z.L. and C.L.; methodology, C.L.; formal analysis, C.L. and Y.G.; investigation, C.L.; resources, Z.L., C.Z.; writing-original draft preparation, C.L.; supervision, Z.L.; project administration, Z.L.; funding acquisition, Z.L. All authors have read and agreed to the published version of the manuscript.

Funding: This research was funded by the Fundamental Research Funds for the Central Universities, Grant No. 2019QN030 and 2017XS059.

Conflicts of Interest: The authors declare no conflicts of interest. The funders had no role in the design of the study; in the collection, analyses or interpretation of data; in the writing of the manuscript or in the decision to publish the results.

\section{References}

1. Fan, W.; Lin, Z.; Kuang, J.; Li, Y. Impact of air staging along furnace height on NOx emissions from pulverized coal combustion. Fuel Process. Technol. 2010, 91, 625-634. [CrossRef] 
2. Flamma, M. Low NOx combustion technologies for high temperature applications. Energy Convers. Manag. 2001, 42, 1919-1935. [CrossRef]

3. Javed, M.T.; Irfan, N.; Gibbs, B.M. Control of combustion-generated nitrogen oxides by selective non-catalytic reduction. J. Environ. Manag. 2007, 83, 251-289. [CrossRef] [PubMed]

4. Yang, W.; You, R.; Wang, Z.; Zhang, H.; Zhou, Z.; Zhou, J.; Guan, J.; Qiu, L. Effects of near-wall air application in a pulverized-coal 300 MWe utility boiler on combustion and corrosive gases. Energy Fuels 2017, 31, 10075-10081. [CrossRef]

5. Chou, S.F.; Daniel, P.L.; Blazewicz, A.J.; Dudek, R.F. Hydrogen sulfide corrosion in low-NOx combustion systerms. J. Mater. Energy Syst. 1986, 7, 361-369. [CrossRef]

6. Zhou, H.; Yang, Y.; Dong, K.; Liu, H.; Shen, Y.; Cen, K. Influence of the gas particle flow characteristics of a low-NOx swirl burner on the formation of high temperature corrosion. Fuel 2014, 134, 595-602. [CrossRef]

7. Harb, J.N.; Smith, E.E. Fireside corrosion in pc-fired boilers. Prog. Energy Combust. Sci. 1990, 16, $155-190$. [CrossRef]

8. Xu, L.-G.; Huang, Y.-J.; Wang, J.; Zou, L.; Yue, J.-F. High-temperature corrosion properties of water wall material 15CrMoG under reducing atmosphere. J. Zhejiang Univ. (Eng. Sci.) 2018, 52. [CrossRef]

9. Zhao, Q.; Zhang, Z.; Cheng, D.; Wang, Y.; Deng, X. High temperature corrosion of water wall materials T23 and T24 in simulated furnace atmospheres. Chin. J. Chem. Eng. 2012, 20, 814-822. [CrossRef]

10. Xu, W.; Tan, H.; Liu, Y.; Wei, B.; Hui, S.e. Research on determination of high temperature corrosion tendency of water walls and limiting concentration range of $\mathrm{H}_{2} \mathrm{~S}$ near walls. Electr. Power 2018, 51. [CrossRef]

11. Jones, R.H.; Baer, D.R.; Windisch, J.C.F. Corrosion enhanced enrichment of sulfur and implications for alloy 22. In Proceedings of the NACE International Corrosion Conference, San Diego, CA, USA, 12-16 March 2006.

12. Petrov, A.I.; Razuvaeva, M.V. Stress corrosion cracking of metals and alloys in aggressive $\mathrm{H}_{2} \mathrm{~S}-\mathrm{CO}_{2}-\mathrm{Cl}^{-}$ environments. Tech. Phys. 2020, 64, 1814-1820. [CrossRef]

13. Rebak, R.B.; Szklarska-Amialowska, Z. The mechanism of stress corrosion cracking of alloy 600 in high temperature water. Corros. Sci. 1996, 38, 971-988. [CrossRef]

14. Davis, J.R. Nickel, Cobalt, and Their Alloys, 1st ed.; ASM International Materials Park: Cleveland, OH, USA, 2000; pp. 125-186.

15. Pardo, A.; Merino, M.C.; Coy, A.E.; Viejo, F.; Arrabal, R.; Matykina, E. Pitting corrosion behaviour of austenitic stainless steels-Combining effects of Mn and Mo additions. Corros. Sci. 2008, 50, 1796-1806. [CrossRef]

16. Ebrahimi, N.; Jakupi, P.; Korinek, A.; Barker, I.; Moser, D.E.; Shoesmith, D.W. Sigma and random grain boundaries and their effect on the corrosion of the Ni-Cr-Mo alloy 22. J. Electrochem. Soc. 2016, 163, C232-C239. [CrossRef]

17. Jakupi, P.; Noël, J.J.; Shoesmith, D.W. Intergranular corrosion resistance of $\sum 3$ grain boundaries in alloy 22. Electrochem. Solid-State Lett. 2010, 13. [CrossRef]

18. Liu, S.; Liu, Z.; Wang, Y.; Tang, J. A comparative study on the high temperature corrosion of TP347H stainless steel, C22 alloy and laser-cladding C22 coating in molten chloride salts. Corros. Sci. 2014, 83, 396-408. [CrossRef]

19. He, X.; Dunn, D.S. Crevice corrosion penetration rates of alloy 22 in chloride-containing waters. Corros. Sci. 2007, 63, 145-158. [CrossRef]

20. Jakupi, P.; Wang, F.; Noël, J.J.; Shoesmith, D.W. Corrosion product analysis on crevice corroded Alloy-22 specimens. Corros. Sci. 2011, 53, 1670-1679. [CrossRef]

21. Chiang, K.T.; Dunn, D.S.; Cragnolino, G.A. Effect of simulated ground water chemistry on stress corrosion cracking of alloy 22. Corros. Sci. 2007, 63, 940-950. [CrossRef]

22. Newman, R.C. The dissolution and passivation kinetics of stainless alloys containing molybdenum-1. Coulometric studies of Fe-Cr and Fe-Cr-Mo alloys. Corros. Sci. 1985, 25, 331-339. [CrossRef]

23. Hayes, J.R.; Gray, J.J.; Szmodis, A.W.; Orme, C.A. Influence of chromium and molybdenum on the corrosion of nickel-based alloys. Corros. Sci. 2006, 62, 491-500. [CrossRef]

24. Lloyd, A.C.; Noël, J.J.; McIntyre, S.; Shoesmith, D.W. Cr, Mo and W alloying additions in Ni and their effect on passivity. Electrochim. Acta 2004, 49, 3015-3027. [CrossRef]

25. Jakupi, P.; Noël, J.J.; Shoesmith, D.W. The evolution of crevice corrosion damage on the Ni-Cr-Mo-W alloy-22 determined by confocal laser scanning microscopy. Corros. Sci. 2012, 54, 260-269. [CrossRef] 
26. Jakupi, P.; Zagidulin, D.; Noël, J.J.; Shoesmith, D.W. The impedance properties of the oxide film on the Ni-Cr-Mo Alloy-22 in neutral concentrated sodium chloride solution. Electrochim. Acta 2011, 56, 6251-6259. [CrossRef]

27. Wang, Q.-Y.; Wang, X.-Z.; Luo, H.; Luo, J.-L. A study on corrosion behaviors of Ni-Cr-Mo laser coating, 316 stainless steel and $X 70$ steel in simulated solutions with $\mathrm{H}_{2} \mathrm{~S}$ and $\mathrm{CO}_{2}$. Surf. Coat. Technol. 2016, 291, 250-257. [CrossRef]

28. Haemers, T.A.M.; Rickerby, D.G.; Lanza, F.; Geiger, F.; Mittemeijer, E.J. Laser cladding of stainless steel with hastelloy. Adv. Eng. Mater. 2001, 3, 242-245. [CrossRef]

29. Barnes, S.; Timms, N.; Bryden, B.; Pashby, I. High power diode laser cladding. J. Mater. Process. Technol. 2003, 138, 411-416. [CrossRef]

30. Cui, C.; Guo, Z.; Liu, Y.; Xie, Q.; Wang, Z.; Hu, J.; Yao, Y. Characteristics of cobalt-based alloy coating on tool steel prepared by powder feeding laser cladding. Optics Laser Technol. 2007, 39, 1544-1550. [CrossRef]

31. Huang, Y. Characterization of dilution action in laser-induction hybrid cladding. Optics Laser Technol. 2011, 43, 965-973. [CrossRef]

32. Chen, L.; Bai, S.-L. The anti-corrosion behavior under multi-factor impingement of Hastelloy C22 coating prepared by multilayer laser cladding. Appl. Surf. Sci. 2018, 437, 1-12. [CrossRef]

33. Fujimagari, H.; Hagiwara, M.; Kojima, T. Laser cladding technology to small diameter pipes. Nucl. Eng. Des. 2000, 195, 289-298. [CrossRef]

34. Wang, Q.-Y.; Zhang, Y.-F.; Bai, S.-L.; Liu, Z.-D. Microstructures, mechanical properties and corrosion resistance of Hastelloy C22 coating produced by laser cladding. J. Alloys Compd. 2013, 553, 253-258. [CrossRef]

35. Li, X.-Z.; Liu, Z.-D.; Li, H.-C.; Wang, Y.-T.; Li, B. Investigations on the behavior of laser cladding Ni-Cr-Mo alloy coating on TP347H stainless steel tube in $\mathrm{HCl}$ rich environment. Surf. Coat. Technol. 2013, 232, 627-639. [CrossRef]

36. Standardization Administration of China. GB/T 5310-2017: Seamless Steel Tubes and Pipes for High Pressure Boiler; Standards Press of China: Beijing, China, 2017; p. 7.

37. Zhao, H.; Wei, Y. Discussion on the mechanisms and factors of the gas side high temperature corrosion in water wall tubes for coal fired boilers. Power Eng. 2002, 22, 1070-1074. [CrossRef] 